\title{
Aktivitas Antioksidan dan Kadar Vitamin C Daging Buah dan Sirup Buah Naga (Hylocereus costaricensis)
}

\author{
Antioxidant activity and Vitamin C levels of Fruit Flesh and Dragon \\ (Hylocereus costaricensis) Fruit Syrup
}

\author{
Titin Aryani*, Isnin Aulia Ulfah Mu'awanah \\ Program Studi Teknologi Laboratorium Medis, Universitas 'Aisyiyah Yogyakarta \\ Jalan Ringroad Barat No.63, Mlangi Nogotirto, Gamping, Area Sawah, Nogotirto, Kec. \\ Gamping, Kabupaten Sleman, Daerah Istimewa Yogyakarta, Indonesia 55592 \\ *Corresponding Author: titinaryanipurnama@gmail.com
}

\author{
Received: August 5, 2019; Revise: November 12, 2019; Accepted: November 28, 2019 \\ DOI : https://doi.org/10.31001/biomedika.v12i2.592
}

\begin{abstract}
ABSTRAK
Telah dilakukan penelitian mengenai aktivitas antioksidan dan kadar vitamin $\mathrm{C}$ pada daging buah naga dan sirup buah naga Hylocereus costaricensis asal Kulon Progo. Tujuan penelitian adalah untuk mengetahui aktivitas antioksidan dan kadar vitamin $\mathrm{C}$ pada daging buah naga dan sirup buah naga asal Kulon Progo. Metode pengambilan sampel dilakukan dengan metode purposive sampling. Metode pengukuran aktivitas antioksidan menggunakan metode perendaman DPPH (1,1-Diphenyl-2-picryl Hidrazil) diukur serapan pada panjang gelombang $517 \mathrm{~nm}$. Metode penentuan kadar vitamin C dilakukan dengan metode titrasi iodimetri menggunakan larutan standar Iodin. Hasil penelitian menunjukkan bahwa rata-rata aktivitas antioksidan daging buah naga adalah $67,81 \%$, sedangkan pada sirup buah naga adalah $42,81 \%$. Adapun kadar vitamin $\mathrm{C}$ pada daging buah naga adalah $12,65 \%$ sedangkan pada sirup buah naga 3,667\%. Dapat disimpulkan bahwa aktivitas antioksidan dan kadar vitamin C daging buah naga lebih tinggi daripada sirup buah naga.
\end{abstract}

Kata kunci: buah naga;sirup buah naga;aktivitas antioksidan;vitamin C

\begin{abstract}
Research on antioxidant activity and vitamin C levels of dragon fruit and Hylocereus costaricensis dragon fruit syrup from Kulon Progo has been conducted. The purpose of this study was to study the antioxidant activity and levels of vitamin $C$ in dragon fruit meat and dragon fruit syrup from Kulon Progo. The sampling method is done by purposive sampling method. The method of measuring antioxidant activity using DPPH (1,1-Diphenyl-2-picryl Hidrazil) immersion method was measured with a wavelength of $517 \mathrm{~nm}$. The method of determining the level of vitamin $C$ is carried out by the method of titration of Iodimetry using a standard solution of iodine. The results showed that the average antioxidant activity of dragon fruit was $67.81 \%$, whereas in dragon fruit syrup was $42.81 \%$. While the level of vitamin $C$ in dragon fruit is $12.65 \%$ while in dragon fruit syrup is $3.667 \%$. Can reduce the levels of antioxidants and vitamin $C$ levels of dragon fruit higher than dragon fruit syrup.
\end{abstract}

Keywords: dragon fruit, dragon fruit syrup, antioxidant activity, vitamin C 


\section{PENDAHULUAN}

Buah naga merupakan tanaman yang belakangan ini banyak dikembangkan di Indonesia karena kaya akan beragam khasiat. Hal ini yang membuat buah naga banyak diburu sebagai buah berkhasiat. Buah naga merah memiliki kandungan senyawa bioaktif yang sangat beragam dan bermanfaat bagi tubuh. Komponen bioaktif tersebut diantaranya adalah asam askorbat, betakaroten, antosianin dan terdapat serat pangan dalam bentuk pektin (Farikha dkk, 2013).

Prior dkk (1998) menyatakan aktivitas antioksidan antosianin lebih besar 2-6 kali dibandingkan antioksidan umum lain seperti asam askorbat dan glutation. Selain itu, banyak bukti menunjukkan bahwa senyawa ini mudah diserap oleh tubuh, berperan dalam perlindungan oksidatif, serta memainkan peranan penting untuk memerangi penyakit jantung maupun berbagai penyakit kanker (Smith dkk, 2000).

Peran buah naga sebagai tanaman berkhasiat obat merupakan hal yang sudah banyak diyakini kebenarannya. Buah naga sangat berperan dalam membantu proses pencernaan, mencegah kanker colon dan diabetes, mengandung substansi yang mampu menetrsalisir racun (logam berat), menurunkan kadar kolesterol dan tekanan darah selain mencegah batuk dan asma. Tingginya kadar potassium, protein, fiber, sodium dan calcium merupakan kelebihan buah naga sebagai buah kesehatan dibandingkan buah buahan lainnya.

Peningkatan radikal bebas di dalam tubuh harus dinetralisir dengan adanya antioksidan di dalam tubuh. Radikal bebas tersebut mengakibatkan reduksi antioksidan endogen, sehingga dibutuhkan asupan antioksidan dari luar tubuh (Aitken dan Shoun, 2008).

Antioksidan eksogen atau bisa juga disebut antioksidan sekunder, bermanfaat dalam menetralkan radikal bebas dengan cara memberikan satu atau lebih elektron sehingga dapat mencegah pembentukan radikal bebas dan menghambat reaksi berantai yang akan berakibat pada kerusakan sel maupun jaringan (Agarwal dkk, 2005). Buah naga merah dipercaya memiliki aktivitas antioksidan yang lebih tinggi dibandingkan buah naga putih dengan komposisi Oxygen radical absorbance capacity (ORAC) 7,6 $\pm 0,1 \mu \mathrm{M} \mathrm{TE} / \mathrm{g}$ bubur (Mahattanatawee, 2006).

Senyawa golongan fenolat seperti flavonoid, tokoferol, dan asam-asam fungsional merupakan jenis antioksidan alami yang secara umum terhadap pada tumbuhan. Buah naga merah mengandung salah satu senyawa golongan fenolat yaitu antosianin sebanyak 8,8 mg/100 g dari daging buahnya. Buah naga merah tersebut juga memiliki aktivitas antioksidan yang lebih tinggi dibanding buah naga putih (Wu et al., 2006). Dalam penelitian Azizah dkk (2017) menyatakan bahwa aktivitas antioksidan penangkal radikal bebas pada buah naga merah keunguan (Hylocereus lemairei) adalah 51,78\%.

Risnayanti (2015) menyatakan bahwa Kadar vitamin $\mathrm{C}$ buah naga putih lebih tinggi dibandingkan vitamin $\mathrm{C}$ buah naga merah. Dimana kadar vitamin C buah naga putih sebesar 7,92 mg/100 gram atau 0,792\% sedangkan kadar vitamin $\mathrm{C}$ buah naga merah sebesar 5,28 $\mathrm{mg} / 100$ gram atau $0,528 \%$, dan terdapat perbedaan antara kadar vitamin $\mathrm{C}$ buah 
naga merah dan buah naga putih dari daerah kabupaten Morowali dengan daerah lainnya. Menurut Azizah dkk (2017) Pada buah naga merah keungunan (Hylocereus lemairei) adalah $24 \mathrm{mg} / 100 \mathrm{~g}$ atau $2,4 \%$.

Salah satu upaya untuk mempertahankan mutu dan memperpanjang masa simpan dari buah naga (Hylocereus costaricensis) adalah dengan mengolahnya menjadi sirup. Karena peran yang begitu penting sebagai tanaman obat, maka kesegaran dan sedikitnya perubahan fisik serta biologisnya sangat diperlukan didalam proses pengolahan buah naga Hylocereus costaricensis menjadi sirup. Sehingga penelitian ini diperlukan untuk mengetahui bagaimana stabilitas kandungan antioksidan dan vitamin $\mathrm{C}$ pada buah naga setelah diolah menjadi sirup.

\section{METODE PENELITIAN}

\section{Alat dan Bahan}

Alat yang digunakan pada penelitian ini adalah alat-alat gelas, lampu cawan penguap, cawan porselen, desikator, oven, vacum, kertas saring, waterbath, dan Spektrofotometer UVVis.

Bahan yang digunakan dalam penelitian ini meliputi buah naga, sirup buah naga (Hylocereus costaricensis), 1,1-difenil-2-pikrilhidrazil (DPPH) p.a,; metanol p.a, asam askorbat (vitamin C), n-butanol p.a, asam asetat dan akuades, Iodium $0,001 \mathrm{~N}$ dan amilum $1 \%$.

\section{Prosedur Penelitian}

\section{Pembuatan Sirup buah Naga (Hylocereus costaricensis)}

Prosedur pembuatan sirup buah naga Hylocereus costarisensis dimulai dengan menyiapkan $300 \mathrm{~mL}$ sari buah naga. Kemudian menambahkan $150 \mathrm{~mL}$ air. Selanjutnya menyiapkan gula sebanyak $50 \%$ dari berat bahan yang telah ditambah air. Kemudian dilanjutkan dengan memasukkan dan memanaskan sebanyak $450 \mathrm{~mL}$ sari buah yang telah ditambah air kedalam panci. Setelah itu menambahkan gula yang telah disiapkan. Dilakukan pengadukan saat proses pemanasan, agar gula larut sempurna dan tercampur secara homogen dengan sari buah naga. Kemudian menambahkan $1 / 2$ sendok teh gelatin dan 1 sendok teh perasa cocopandan. Setelah matang, dilanjutkan dengan memasukkan sirup buah naga ke dalam botol untuk diuji.

\section{Pembuatan Ekstrak Metanol Daging dan Sirup Buah Naga (Hylocereus costaricensis)}

Sebanyak 500 g sampel daging buah naga (Hylocereus costaricensis), dipotong kecil-kecil. Untuk pembuatan ekstrak dari sirup buah naga, dibutuhkan $500 \mathrm{~mL}$ sirup kemudian sampel daging buah dan sirup buah naga dimaserasi selama 3 hari menggunakan $4 \mathrm{~L}$ pelarut metanol. Kemudian, dilanjutkan dengan melakukan penggantian pelarut setiap 24 jam dan dilakukan pengadukan setiap saat. Filtrat hasil maserasi tersebut kemudian dipekatkan menggunakan vakum, hingga akhirnya diperoleh ekstrak daging maupun ekstrak sirup buah naga (Hylocereus costarisensis). 
Uji Aktivitas Antioksidan Ekstrak Metanol Daging dan Sirup Buah Naga (Hylocereus costaricensis) dengan Metode DPPH

Pengukuran aktivitas antioksidan dari ekstrak methanol daging dan sirup buah naga (Hylocereus costarisensis) dimulai dengan cara menyiapkan ektrak metanol buah naga dan sirup buah naga dengan konsentrasi $50 \mu \mathrm{g} / \mathrm{mL}, \quad 75$ $\mu \mathrm{g} / \mathrm{mL}, 100 \mu \mathrm{g} / \mathrm{mL}, 125 \mu \mathrm{g} / \mathrm{mL}$ dan 150 $\mu \mathrm{g} / \mathrm{mL}$. Kemudian sebanyak $1 \mathrm{~mL}$ ekstrak metanol daging buah dan sirup buah naga (Hylocereus costaricensis) ditambahkan kedalam $2 \mathrm{~mL}$ larutan $\mathrm{DPPH} \quad 0,1 \mathrm{mmol} / \mathrm{L}$. Selanjutnya, campuran tersebut, kemudian dikocok hingga homogen. Perlakukan ini juga dilakukan pada larutan blanko dan kontrol positif yaitu vitamin $\mathrm{C}$ dengan konsentrasi $2 \mu \mathrm{g} / \mathrm{mL}, 3 \mu \mathrm{g} / \mathrm{mL}, 4 \mu \mathrm{g} / \mathrm{mL}$ $5 \mu \mathrm{g} / \mathrm{mL}$, dan $6 \mu \mathrm{g} / \mathrm{mL}$. Setelah itu, campuran diinkubasi pada tempat gelap selama 30 menit pada suhu ruang. Selanjutnya larutan blanko, kontol positif dan sampel ekstrak buah dan sirup buah naga Hylocereus costaricensis diukur absorbansinya menggunakan Spektrofotmeter UV-Vis pada panjang gelombang $517 \mathrm{~nm}$.

Penentuan Kadar Vitamin Buah Naga dan C Sirup Buah Naga (Hylocereus costaricensis) Metode Titrasi Iodimetri

Prosedur penentuan kadar vitamin

$\mathrm{C}$ dimulai dengan mengupas dan membuang biji buah naga Hylocereus costaricensis yang telah matang. Kemudian memotong buah hingga ukuran kecil, sekitar 1x1 cm. Selanjutnya menimbang sebanyak $200 \mathrm{~g}$ potongan buah naga dan menghancurkannya dengan menggunakan mesin penghancur buah seperti blender hingga menghasilkan bentuk bubur. Kemudian menimbang sebanyak 10 gram bubur dan memasukkannya ke dalam labu takar $100 \mathrm{~mL}$ dan ditandabataskan. Selanjutnya disaring untuk mendapatkan filtrat.

Tahap selanjutnya adalah setelah diperoleh filtrat adalah memasukkan 10 $\mathrm{mL}$ filtrat ke dalam labu erlenmeyer 250 $\mathrm{mL}$ dan menambahkan $20 \mathrm{~mL}$ akuades. Kemudian menambahkan indikator amilum 1\%. Sampel buah naga dan sirup buah naga dititrasi menggunakan larutan iodium 0,01 N. Titrasi dihentikan ketika titik akhir titrasi tercapai yang ditandai dengan munculnya warna biru yang stabil dalam 15 menit.

\section{HASIL DAN PEMBAHASAN}

\section{Aktivitas Antioksidan}

Hasil penelitian ini menunjukkan bahwa buah naga dan sirup buah naga merupakan bahan pangan yang mengandung antioksidan. Hal ini dapat dilihat dari adanya aktivitas antioksidan buah naga dan sirup buah naga (Hylocereus costaricensis) pada hasil penelitian. Antioksidan merupakan senyawa penyumbang satu atau lebih elektron. Senyawa ini memiliki berat molekul yang relatif kecil, namun mampu menghambat berkembangnya reaksi oksidasi dengan cara mencegahnya membentuk radikal bebas. Terdapat beberapa metode yang dapat diterapkan untuk mengukur aktivitas antioksidan. Pada penelitian ini metode yang dipilih untuk mengukur aktivitas antiokasidan adalah dengan menggunakan metode DPPH. 
Metode DPPH (2,2-diphenyl-1picrylhydrazyl) merupakan salah satu metode yang paling banyak digunakan untuk memperkirakan efektivitas kinerja dari suatu zat yang berperan sebagai antioksidan. Metode pengujian ini berdasarkan pada kemampuan substansi antioksidan dalam menetralisir radikal bebas. Radikal bebas DPPH merupakan radikal bebas yang stabil pada suhu ruang dan larut dalam metanol. Sifat stabil DPPH dikarenakan memiliki sebuah molekul yang didelokalisir dari molekul awalnya. Delokalisasi tersebut akan memberikan respon berupa warna. Warna tersebut memberikan absorbansi maksimum yang diperoleh pada panjang gelombang $517 \mathrm{~nm}$. Hal inilah yang mendasari pemilihan panjang gelombang Spektrofotometer UV-Vis pada saat pengukuran absorbansi peredaman radikal pada penelitian ini.

Alasan lainnya terkait pemilihan metode DPPH untuk mengukur aktivitas antioksidan pada penelitian ini adalah karena metode ini dapat dikerjakan dengan cepat, sederhana, sensitif, mudah dan hanya membutuhkan sedikit sampel. Adapun pemilihan metanol sebagai pelarut karena metanol dapat melarutkan kristal DPPH dan memiliki sifat yang dapat melarutkan komponen nonpolar di dalamnya (Molyneux, 2004).
Perubahan warna yang terjadi pada saat pengukuran aktivitas antioksidan pada penelitian ini yaitu dari warna ungu menjadi kuning. Perubahan warna tersebut disebabkan absorptivitas molar radikal DPPH pada $517 \mathrm{~nm}$. Ketika elektron tak berpasangan pada radikal DPPH berpasangan dengan atom hidrogen membentuk DPPH-H tereduksi. Perubahan tersebut dapat diukur dengan Spektrofotometer UVVis. Jumlah absorbansi yang terukur akan sebanding dengan konsentrasi. Berubahnya intensitas warna menjadi semakin menurun disebabkan oleh berkurangnya ikatan rangkap terkonjugasi pada radikal DPPH yang berpasangan dengan hidrogen dari zat antioksidan. Hal ini menyebabkan tidak ada elektron yang memiliki kesempatan untuk beresonansi.

Aktivitas antioksidan buah naga diduga juga diperngaruhi oleh masa pematangan buah. Ketika kematangan buah semakin meningkat maka aktivitas antioksidannya juga akan semakin meningkat. Antosianin sebagai salah satu sumber antioksidan pada buah naga juga meningkat pada buah yang semakin matang. Berdasarkan penelitian ini, aktivitas antioksidan pada daging buah dan sirup buah (Hylocereus costarisensis) ditampilkan pada Tabel 1.

Tabel 1. Aktivitas Antioksidan dan antosianin Daging Buah Naga Hylocereus costaricensis

\begin{tabular}{ccc}
\hline Pengukuran & \multicolumn{2}{c}{ Aktivitas Antioksidan (\%) } \\
\cline { 2 - 3 } Ke-n & Daging Buah & Sirup Buah Naga \\
\hline 1 & 67,76 & 43,15 \\
2 & 68,51 & 42,92 \\
3 & 67,53 & 42,08 \\
4 & 67,45 & 43,10 \\
Rata-rata & $\mathbf{6 7 , 8 1}$ & $\mathbf{4 3 , 8 1}$ \\
\hline
\end{tabular}


Hasil penelitian yang ditunjukkan pada Tabel 1 memperlihatkan bahwa aktivitas antioksidan pada daging Buah Naga (Hylocereus costaricensis) memiliki rata-rata aktivitas antioksidan sebesar $67,81 \%$ sedangkan pada daging buah naga memiliki aktivitas antoksidan sebesar 43,81\%. Aktivitas antioksidan daging buah naga pada penelitian ini relatif sejalan dengan hasil penelitian Nataliani dkk (2018) yang menyatakan bahwa aktivitas antioksidan ekstrak buah Naga (Hylocereus costaricensis) pada waktu penyimpanan 3 hari pada suhu ruang menghasilkan aktifitas antioksidan 62,18\%. Pada penelitian ini, terjadi penurunan aktivitas antioksidan buah naga (Hylocereus costaricensis) setelah diolah menjadi sirup. Penurunan aktivitas antioksidan diduga disebabkan proses pemasakan buah pada saat pengolahan sirup.

\section{Kadar Vitamin C}

Vitamin C pada buah nada dan sirup buah naga merah (Hylocereus costarisensis) pada penelitian ini, memiliki struktur kimia yang mirip dengan struktur monosakarida. Perbedaannnya, vitamin $\mathrm{C}$ mengandung gugus enediol. Gugus enediol pada vitamin $\mathrm{C}$ berfungsi dalam sistem perpindahan hidrogen yang menunjukkan peranan penting dari vitamin ini sebagai antioksidan. Vitamin $\mathrm{C}$ mudah teroksidasi menjadi bentuk dehidro. Secara fisiologis, vitamin $\mathrm{C}$ dan dehidro berperan aktif dan ditemukan di dalam tubuh. Paparan cahaya, pemanasan dan suasana basa dapat mengoksidasi Vitamin $\mathrm{C}$ menjadi asam
L-dehidroaskorbat. Reaksi vitamin C menjadi asam L-dehidroaskorbat bersifat reversibel Selanjutnya jika asam Ldehidroaskorbat teroksidasi lebih lanjut akan terbentuk asam 2,3 diketogulonik. Kemudian asam 2,3 diketogulonik berubah menjadi asam oksalat dan 1asam treonik. Reaksi-reaksi ini tidak bersifat reversibel (Thurnham \& Bender, 2000).

Vitamin $\mathrm{C}$ yang terdapat dalam buah naga dan sirup buah naga Hylocereus costaricensis pada penelitian ini akan bertindak sebagai antioksidan di dalam tubuh. Selain itu, vitamin $C$ juga akan berperan dalam membantu proses penyerapan mineral besi di dalam usus sehingga dapat mencegah terjadinya anemia defisiensi besi. Selain fungsinya sebagai antioksidan, vitamin $\mathrm{C}$ juga berfungsi dalam memacu kesehatan pembuluh kapiler, mencegah sariawan dan gusi bengkak serta menjaga kehalusan kulit dan mencegah tanggalnya gigi. Dosis vitamin C yang tinggi diduga mampu meningkatkan kekebalan tubuh dan mencegah infeksi.

Kadar Vitamin C pada daging dan buah naga Hylocereus costarisensis pada penelitian ini ditetapkan dengan metode titrasi Iodimetri. Titrasi ini menggunakan larutan Iodium 0,01 N dan indikator amilum 1\%. Dalam setiap 1 $\mathrm{mL}$ larutan Iodium $0,01 \mathrm{~N}$ yang digunakan untuk mencapai titik akhir titrasi, setara dengan 0,88 mg vitamin C (Wahyuni, 2011). Berdasarkan penelitian ini, diperoleh hasil bahwa kadar vitamin C pada daging dan sirup buah naga Hylocereus costaricensis ditampilkan pada Tabel 2. 
Tabel 2. Kadar Vitamin C Daging Buah dan Sirup Buah Naga Hylocereus costaricensis

\begin{tabular}{ccc}
\hline \multirow{2}{*}{$\begin{array}{c}\text { Pengukuran } \\
\text { Ke }\end{array}$} & \multicolumn{2}{c}{$\begin{array}{c}\text { Vitamin C } \\
(\mathbf{m g} / \mathbf{1 0 0 m L})\end{array}$} \\
\cline { 2 - 3 } & Daging Buah & Sirup buah naga \\
\hline 1 & 12,65 & 3,250 \\
2 & 12,65 & 3,675 \\
3 & 12,66 & 3,512 \\
4 & 12,62 & 3,961 \\
Rata-rata & $\mathbf{1 2 , 6 5}$ & $\mathbf{3 , 6 6 7}$ \\
\hline
\end{tabular}

Hasil penelitian pada Tabel 2 menunjukkan bahwa kadar vitamin $\mathrm{C}$ pada daging Buah Naga Hylocereus costaricensis memiliki rata-rata kadar vitamin C sebesar 12,65 $\mathrm{mg} / 100 \mathrm{~g}$ sedangkan pada sirup buah naga memiliki rata-rata vitamin $\mathrm{C}$ sebesar $3,667 \mathrm{mg} / 100 \mathrm{~mL}$.

Kadar vitamin $\mathrm{C}$ buah naga pada penelitian ini lebih tinggi dari pada hasil penelitian Risnayanti dkk (2015) yang menyatakan bahwa kadar vitamin C buah naga putih sebesar 7,92 mg/100 gram (hampir setara dengan 7,92 mg/100 mL) sedangkan kadar vitamin C buah naga merah sebesar $5,28 \mathrm{mg} / 100$ gram (hampir setara dengan 5,28 mg/100 $\mathrm{mL}$ ). Penelitian Risnayanti dkk (2015) juga menyebutkan terdapat perbedaan antara kadar vitamin $\mathrm{C}$ buah naga merah dan buah naga putih dari daerah kabupaten Morowali dengan daerah lainnya. Sedangkan hasil penelitian Azizah dkk (2017) menyebutkan bahwa pada buah naga merah keunguan (Hylocereus lemairei) adalah $24 \mathrm{mg} / 100$ g. Perbedaan pada penelitian ini diduga disebabkan oleh perbedaan spesies buah naga yang diteliti dan habitat buah naga.

Penelitian ini berbeda dengan penelitian Arel dkk (2017) dengan subjek penelitian yang sama dengan penelitian ini yaitu daging buah naga Hylocereus costarisensis. Penelitian Arel dkk (2017) menyebutkan bahwa kadar vitamin $\mathrm{C}$ buah naga Hylocereus costarisensis yang ditanan di Lubuk Minturun, Padang adalah sebanyak $0,2673 \mathrm{mg} / \mathrm{g}$ atau setara dengan 26,73 $\mathrm{mg} / 100 \mathrm{~g}$. Sedangkan pada penelitian ini Hylocereus costarisensis yang ditanam di Kulon Progo memiliki kadar vitamin C $12,65 \mathrm{mg} / 100 \mathrm{~mL}$ (hampir setara dengan 12,65 $\mathrm{mg} / 100 \mathrm{~g})$. Perbedaan mungkin disebabkan oleh tempat tumbuh buah naga. Faktor lainnya bisa saja disebabkan oleh variasi penyimpanan dan metode pengukuran kadar vitamin $\mathrm{C}$ yang digunakan. Pada penelitian ini, metode yang digunakan adalah titrasi iodimetri, sedangkan pada penelitian Arel dkk (2017) menggunakan metode Spektrofotometer Uv-Vis.

Pada penelitian ini terdapat perbedaan antara kadar vitamin $\mathrm{C}$ pada buah naga dan sirup buah naga Hylocereus costaricensis. Perbedaan mungkin disebabkan pengaruh suhu pada saat pengolahan buah naga menjadi sirup. Selain pengaruh suhu, penyimpanan juga diduga mempengaruhi kadar vitamin C. Menurut Saati (2010) penyimpanan akan mempengaruhi penurunan nilai gizi, khususnya vitamin C. Produk-produk yang memiliki kadar vitamin $\mathrm{C}$ yang tinggi dapat mengalami penurunan kadar vitamin C. Hal ini disebabkan sifat vitamin $\mathrm{C}$ yang mudah mengalami oksidasi (Saati, 2010). Sehingga pada 
penelitian ini, setelah proses pengolahan menjadi sirup, kadar vitamin $\mathrm{C}$ buah naga Hylocereus costarisensis menurun karena proses meningkatnya suhu akibat proses memasak. Hal ini sesuai dengan pendapat Syafutri dan Pratama (2006), bahwa selama dalam tahap-tahap pengolahan dapat terjadi kehilangankehilangan zat gizi.

Penurunan kadar vitamin $\mathrm{C}$ pada buah naga Hylocereus costarisensis setelah diolah menjadi sirup pada penelitian ini dapat juga disebabkan oleh terjadinya reaksi pencoklatan non enzimatik. Pencoklatan ini merupakan tahap awal dari berlangsungnya reaksi maillard. Reaksi ini dapat terjadi karena vitamin C merupakan reduktor dan berfungsi sebagai pembentuk warna coklat non enzimatik. Pencoklatan ini berakibat pada menurunnya kadar vitamin C, gula, dan protein (Safari, 2007).

Kehilangan vitamin $\mathrm{C}$ pada buah naga Hylocereus costarisensis pada penelitian ini diduga akan berlangsung terus sepanjang pengolahan, oleh pengaruh pencucian, pengecilan ukuran dan penghancuran. Terkenanya jaringan buah oleh udara akan menyebabkan rekasi oksidasi dan menyebabkan berkurangnya vitamin C. Selama penyimpanan, kehilangan vitamin $\mathrm{C}$ akan terus berlangsung dan dipengaruhi suhu. Semakin tinggi suhu penyimpanan, maka akan semakin besar terjadinya kerusakan zat gizi (Wardani, 2007).

\section{KESIMPULAN}

Kesimpulan dari penelitian ini adalah rata-rata aktivitas antioksidan buah naga Hylocereus costarisensis adalah $67,81 \%$ sedangkan pada sirup buah naga Hylocereus costarisesnsis adalah $42,81 \%$. Adapun kadar rata-rata vitamin $\mathrm{C}$ buah naga Hylocereus costarisesnsis adalah 12,65 mg/100 mL sedangkan pada sirup buah naga Hylocereus costarisesnsis adalah $3,661 \mathrm{mg} / 100 \mathrm{~mL}$. Terlihat bahwa aktivitas antioksidan dan vitamin $\mathrm{C}$ buah naga lebih tinggi dibandingkan setelah diolah menjadi sirup buah naga.

\section{UCAPAN TERIMA KASIH}

Penulis berterimakasih kepada Kementerian Riset Teknologi dan Perguruan Tinggi (Kemenristek DIKTI) yang telah mendukung dan mendanai pelaksanaan penelitian ini dalam Hibah Penelitian Dosen Pemula (PDP) DIKTI dengan nomor kontrak B/1435.17/L5/RA.00/2019 tanggal 15 April 2019. Semoga Kemenristek DIKTI semakin maju dan berkembang. Aamiin.

\section{DAFTAR PUSTAKA}

Aitken, R. J. and Shoun, D. R. 2008. Antioxidant System and Oxidative Stress in The Testes. London Bioscience. Chapter 9. 154-171.

Agarwal, A., Prabakaran, S. A., and Said, T. M. 2005. Prevention of Oxidative Stress Injury to Sperm. Journal Andrologi. 26 (6): 654660.

Apriyanto, D. R. dan C. Frisqila. 2016. Perbandingan Efektivitas Ekstrak dan Fermentasi Buah Naga Merah terhadap Penurunan Kadar Kolesterol Low Density Lipoprotein (LDL) pada Tikus Putih yang dibuat Hiperkolesterolemia. Tunas Media Jurnal Kedokteran dan Kesehatan. 3(3) : - .

Arel Afdhil, B.A. Martinus, dan Satiti Ambar Ningrum. 2017. Penetapan Kadar Vitamin C pada Buah Naga Merah (Hylocereus coctarisensis (F.A.C. Weber) Britton dan Rose. Dengan metode Spektrofotometer Uv-Vis. Scientia. 7(1):1-5. Februari 2017. 
Azizah Zikra, Zulharmita, dan Eki Zulfian. 2017. Uji Aktivitas Antioksidan dan Penetapan Kadar Vitamin C Ekstrak Buah Naga Merah Keunguan (Hylocereus Lemairei (Hook.) Britton \& Rose) Secara Spektrofotometri Uv-Vis. Jurnal Farmasi Higea. 9(1):41-47.

Farikha, I. N., Choirul, A., dan Esti, W. 2013. Pengaruh Jenis dan Konsentrasi Bahan Penstabil Alami terhadap Karakteristik Fisikokimia Sari Buah Naga Merah (Hylocereus polyrhizus) Selama Penyimpanan. Jurnal Teknosains Pangan. $2: 0733-2302$.

MacDougall DB. 2002. Colour in Food: Improving Quality. CRC Press, Boca Raton. Gómez-Plaza E, Miñano A, dan López-Roca JM. 2006. Comparison of chromatic properties, stability and antioxidant capacity of anthocyanin-based aqueous extracts from grape pomace obtained from different vinification methods.

Mahattanatawee, K., Manthey, J. A., Luzio, G., Talcott, S. T.,Goodner, K., and Baldwin, E. A. 2006. Total Antioxidant Activity and Fiber Content of Select Florida Grown Tropical Fruits. Journal of Agricultural and Food Chemistry. 54 (19): 7355-7363.

Molyneux P., 2004. The Use of Stable Free Radical Diphenylpicrylhydrazyl (DPPH) for Estimating Antioksidant Activity. Songklanakarin Journal Science and Technology. 26(2) : 211-219.

Nataliani Maria Monasias, Khemasili Kosala, Ika Fikriah, Ronny Isnuwardana, dan Swandari Paramita. 2018. Pengaruh penyimpanan dan pemanasan terhadap Stabilitas Fisik dan Aktivitas Antioksidan Larutan Pewarna Alami Daging Buah Naga (Hylocereus costaricensis). 11(1):1-10. Jurnal Tumbuhan Obat Indonesia. Agustus 2018.

Prior, R.L., Cao, G., Martin A., Soffic E., McEwen J., O'Brien C., Lishchner N., Ehlenfeldt M., Kalt W., Krewer G., and Mainland C.M. 1998. Antioxidant capacity as influenced by total phenolic and antochyanin content, maturity and variety of Vaccanium Spesies. Journal Agriculture Food Chemistry. 46 (7):2686-2693.

Pujiharjo, D. 2010. Kajian Aktivitas Antioksidan Sirup Buah Naga Kulit Merah Daging Putih. Skripsi. Fakultas Pertanian UNS: Surakarta.

Saati, E. A. 2010. Identifikasi dan uji kualitas pigmen kulit buah naga merah pada beberapa umur simpan dengan perbedaan jenis pelarut. GAMMA. 6(1):25 - 34 .

Safari, R. 2007. Penentuan vitamin $c$ dalam manisan nanas secara spektrofotometri dengan pereaksi metilen biru. Yogyakarta: Universitas Islam Negeri Sunan Kalijaga.

Smith, M.A.L., K.A. Marley, D. Seigler, K.W. Singletary and B. Meline. 2000. Bioactive properties of wild bluberry fruits. Journal Food Science. 65 (2): 352-356.

Syafutri, M. I., dan Pratama, F. 2006. Sifat fisik dan kimia buah mangga selama penyimpanan dengan berbagai metode pengemasan. Jurnal Teknologi dan Industri Pangan, 17(1), 43 - 47.

Risnayanti, Sri Mulyani Sabang, dan Ratman 2015. Analisis Perbedaan Kadar Vitamin C Buah Naga Merah (Hylocereus Polyrhizus) dan Buah Naga Putih (Hylocereus Undatus) yang Tumbuh Di Desa Kolono Kabupaten Morowali Provinsi Sulawesi Tengah. Jurnal Akademi Kimia. 4(2):91-96. Mei 2015.

Thurnham, D. I., and Bender, D. A. 2000. Water soluble vitamins, dalam human nutritions and dietatics. United kingdom:Harcourt.

Wahyuni, R. 2011. Pemanfaatan Kulit Buah Naga sebagai Sumber Antioksidan dan Pewarna Alami pada Pembuatan Jelly. Jurnal Teknologi Pangan. 2(1); 32 - 40.

Wardani, L. A. 2007. Validasi Metode Analisis dan Penentuan Kadar Vitamin $C$ pada Minuman Buah Kemasan dengan Spektrofotometri Uv-Visible. Jakarta: Universitas Indonesia.

Wu, L. C., Hsu, H. W., Chen, Y., Chiu, C.C., and Ho, Y. I. 2006. Antioxidant and Antiproliferative Activities of Red Pitaya. Food Chemistry. Volume, 95: 319-327 